\title{
PETROLEUM POTENTIAL OF CAMPANO-MAASTRICHTIAN SHALES OF ANAMBRA BASIN, SOUTH ASTERN NIGERIA
}

O. A. ADEAGBO

(Received 14, November 2008; Revision Accepted 26, March 2009)

\author{
ABSTRACT
}

Over 6,000 meters thick terrigeneous sediment (mainly shale/ siltstones/lithologies) of campano Maastrichtian age has been recorded in the Anambra basin. These shale/siltstones lithologies have been reported to be rich in organic matter and had fulfilled other relevant condition for hydrocarbon source rock potential. However, only few patches of hydrocarbon shows have been documented elsewhere in the basin. This work attempts to critically evaluate the hydrocarbon source potential of the organic rich shale sediments in the basin.

A sample set of 40 ditch cuttings of manly shale lithologies retrieved at different depths intervals from 2 well were subjected to standard geo-chemical and organic petrography investigations. The samples were analyzed for the total carbon content (TOC), extract yield, organic matter types and organic maturity level.

As screening criteria, all the sample set were subjected to TOC measurement (LECO). The TOC values range from $0.81-1.40 \%$ (AKU2) and from $0.82-1.81 \%$ (AMA.1) most of the samples meet up with minimum required TOC value ().5\%) for a siliciclastic sediments to be hydrocarbon prone. Extract yield range from 30.0 to $180.5 \mathrm{ppm}$ (AKU2) and 30.0 to 128ppm (AMA 1). The Rock-Eval Pyrolysis data HI vs OI revealed that the samples fall within types II \& III kerogen. This corroborates with the results of the maceral analysis. The maceral composition is mainly vitrinitic and liptinitic of terrestrial origin, which are over 65 volume percent.

The shales are moderately rich in organic matter. Extract yields and the bitumen ratio (mg HC/g TOC) revealed that these samples are at immature stage of Hydrocarbon generation. This is also supported by Tmax values of between $430-490^{\circ} \mathrm{C}$.

KEY WORDS:- Terrigeneous, Campano - Maastrichtian, Vitrinit, Liptinite, Rock-Eval.

\section{INTRODUCTION}

Anambra basin is a cretaceous depocenter containing thick sequences of elastic sediment ranging from bituminous shales lignites through sandstone and marl and it's Paleo-geographical strategic positioning as the proto-Niger Delta provides and ideal ground for geochemical evaluation of shales as oil/gas prone source rock. Various published work e.g Ekweozor and Gormly [1983) Petters and Ekweozor (1982) have revealed that the Campano-Maastrichtian Nkporo shale exhibit characteristics of potential hydrocarbon source system for a series of oil/gas and condensate shows found within Ajali sandstone

The study area is roughly a triangular Sedimentary basin. It covers about $40,000 \mathrm{sq} \mathrm{km}$. the southern boundary coincides with the Northern boundary of the Niger Delta basin. Anambra Basin extends northward beyond lower Benue River, but this view deals chiefly with the southern portion of the basin.
The two well studied are located within Enugu, southeastern part of Nigeria. The studied area is within Anambra basin, it covers an area of approximately 218 square kms bounded by Latitudes $5.5^{\circ}$ and $6.5^{\circ}$ north and longitude $6.5^{\circ}$ and $7.5^{\circ}$ east. Fig1

Since the discovery of petroleum in Niger Delta by Shell Petroleum Company of Nigeria in 1956, an increase in commercial exploration and exploitation have been going on with focus on the detection of suitable reservoir rocks and location of structural traps using geophysical methods. Recently, efforts are now on source rocks and their maturity.

There are a good number of research and geological studies in Niger Delta and Anambra Basin. Most of these works were carried out by oil companies operating in the area, but with only very few publication on source rock which have proved to be great geological interest and controversial Akaegbobi (1995). It was also observed that

O. A. Adeagbo, Department of Geology Polytechnic, Ibadan.

Postal Address: P.O. Box 27744 Agodi Post Office Ibadan, Oyo State 


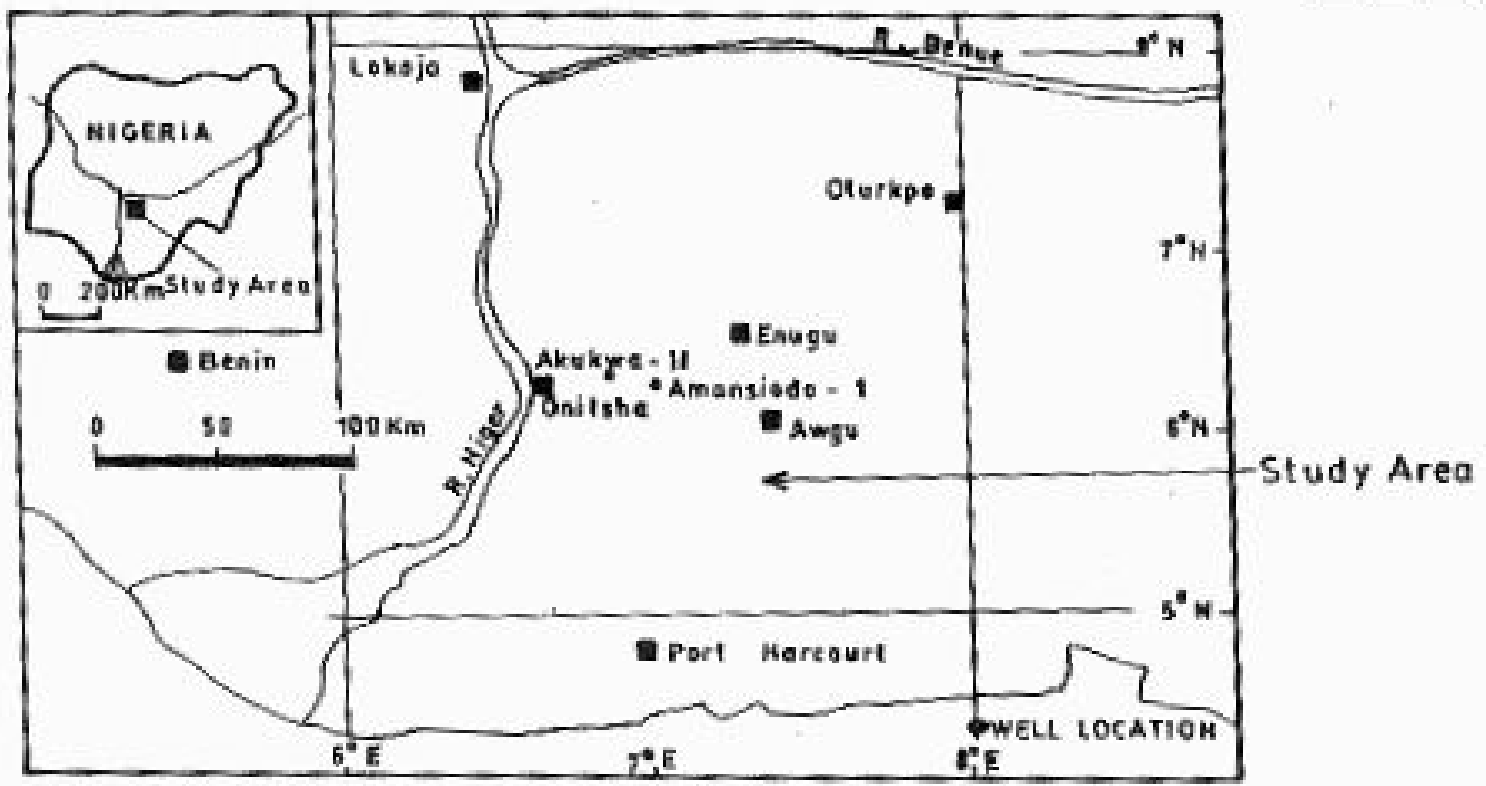

Fig-1:L ocation Map of the Study Area Showing the position

of Akukwa-ll and Amansiodo- I wells.

some sediment sample in the Anambra Basin show very low vitrinity reflectance, Ekweozor \& Gormly (1983). This allows the assumption that the formation of the petroleum hydrocarbon took place under low temperature condition. It could also be possible that the migration effect (Impregnation) of the petroleum hydrocarbon might have influenced the low vitrinity reflectance.

The Tectonic conditions of Anambra Basin make it ideal for study. In this respect, the organic geochemical investigation could be used to:

- Determine the Organic richnes of the shale sediments

- $\quad$ Determine the quality of the kerogen.

- $\quad$ Determine the sediment maturity and finally.

- Evaluate the hydrocarbon potential of the basin sediments.

The two wells basic for selection because they both penetrated through the entire sediments of Anambra basin and located within the basin, in particular the Akukwa-II and Amansiodo-I wells fig 2. The sediments selected are organic-rich. They are Nkporo shale sediments at various depths ranging from 1,400meters to 4,000 meters fig 3 and fig 4 .

GEOLOGICAL SETTING; there are a lot of hypothesis about the origin of Benue Trough, but the most acceptable model is that of the plate tectonic concepts which appears to account more satisfactorily for the present arrangement of transform features zones in the gulf of Guinea region. The Anambra basin (covering an area of about $2.18 \mathrm{Sqkm}$ ) is located in south central part of Nigeria. Extending northwards in the lower Benue River. The basin forms a boundary with tertiary Niger Delta basin to the south. As one of the component basin of the Benue Aulacogen, the Anambra basin reflects the features of the break-up of the Gondwana supracontinent. Olade (1975), Akaegbobi et al [2000]. The basin summary has been given by various workers, Agagu (1986), Agagu and Eweozor (1980), Agagu etal (1986) Ekweozor and Gormly (1983); Avbovbo (1978a). The sediment infill of the southern Nigeria Basin has been controlled by three main tectonic phases. The riftlike Benue Abakaliki trough was formed during the first tectonic phase (Albian) and filled by the sediment of three major cycles. The second phase resulted in the folding and in subsidence of the Anambra Basin which Subsequently was filled by second sedimentary cycles. The Nigeria Delta Basin was however formed during the third phase (upper Eocene). The cretaceous Anambra depositional site reflect a mega-facies region receiving sediments within two depositional cycles ranging from campanian to Eocene 


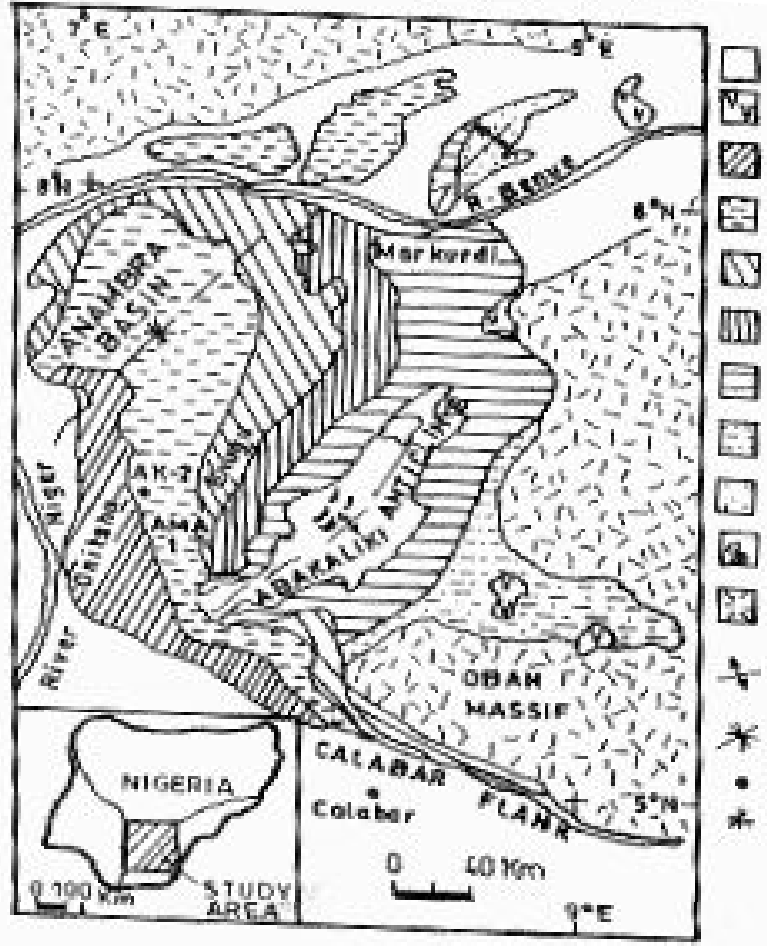

PLEIST OCENE-RECENT SEDIMENTS

TERTIARY VOLCANICS

TERTIARY SEDIMENTS

COAL MEASURES

ASATA NKPORO SHALES

AWGU FORMATION

EZE AKU EORMATION

ODUKPANI FORMATION

ASU RTYER GROUP

CRETACEOUS VOLCANICS

PRECAMBRIAN BASEMENT

ANTICLINAL AXIS

SYNCLHAL AXIS

AKUKWA - 2 WELL.

AMANSIODO - 1 WELL.

\section{Fig. 2:GEOLOGICAL MAP OF THE LOWER BENUE TROUGH SHOWING THE POSITION OF AKUKWA - 2 AND AMANSIOSO-1 WELLS ADAPIED FROM}

Reyment, (1965). The sediments are mainly continental fluvio-deltaic and shallow marine sedimentation millieux. Azu river group, Odukpani Formation, Eze Aku shale groug, Awgu shale, Nkporo shale, Mamu formation, Ajali sandstone, Nsukka formation, Imo shale and Ameki group. Fig;2.

\section{MATERIALS AND METHODS}

Anambra basin has received considerable geological interest since 1903, when exploration for coal deposits in the basin were published by Bain (1924 and 1930), Wilson and Bain (1928). Based on the fact that geology and stratigraphy of the Benue trough has been well established and many works of the Anambra basin has been published. For this work, subsurface sample materials were selected for study. The samples are mainly ditch cuttings from two deep appraisal wells (Ama-1 and Aku-11) located at the south western part of the Basin, The samples are from the Geological survey Agency, Kaduna. These wells penetrated all the formations in the Basin; of interest are the capanomaastrichtian sediments. The depth examined for Amansiodo-I well is between 1,400 meters to 2,000 meters and 3,330 meters to 3,900 meters for Akukwa-II well Fig 3 \& 4 . The 
LITHOLOGIC LOG: AMANSIODO - I WELL

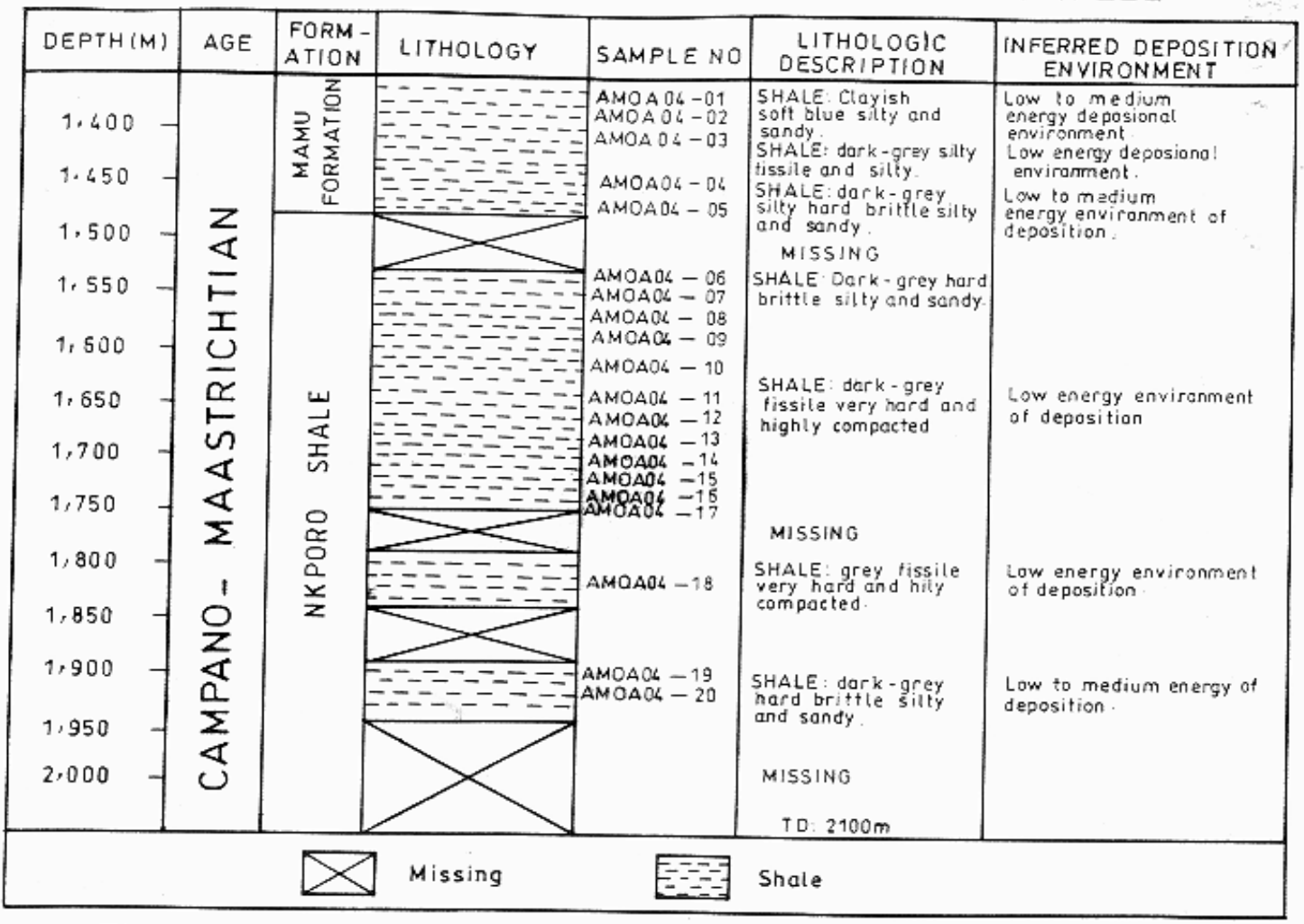

Fig.3: Lithostratigraphic log of Amansiodo-I Well .

LITHOLOGIC LOG: AKU -II WELL.

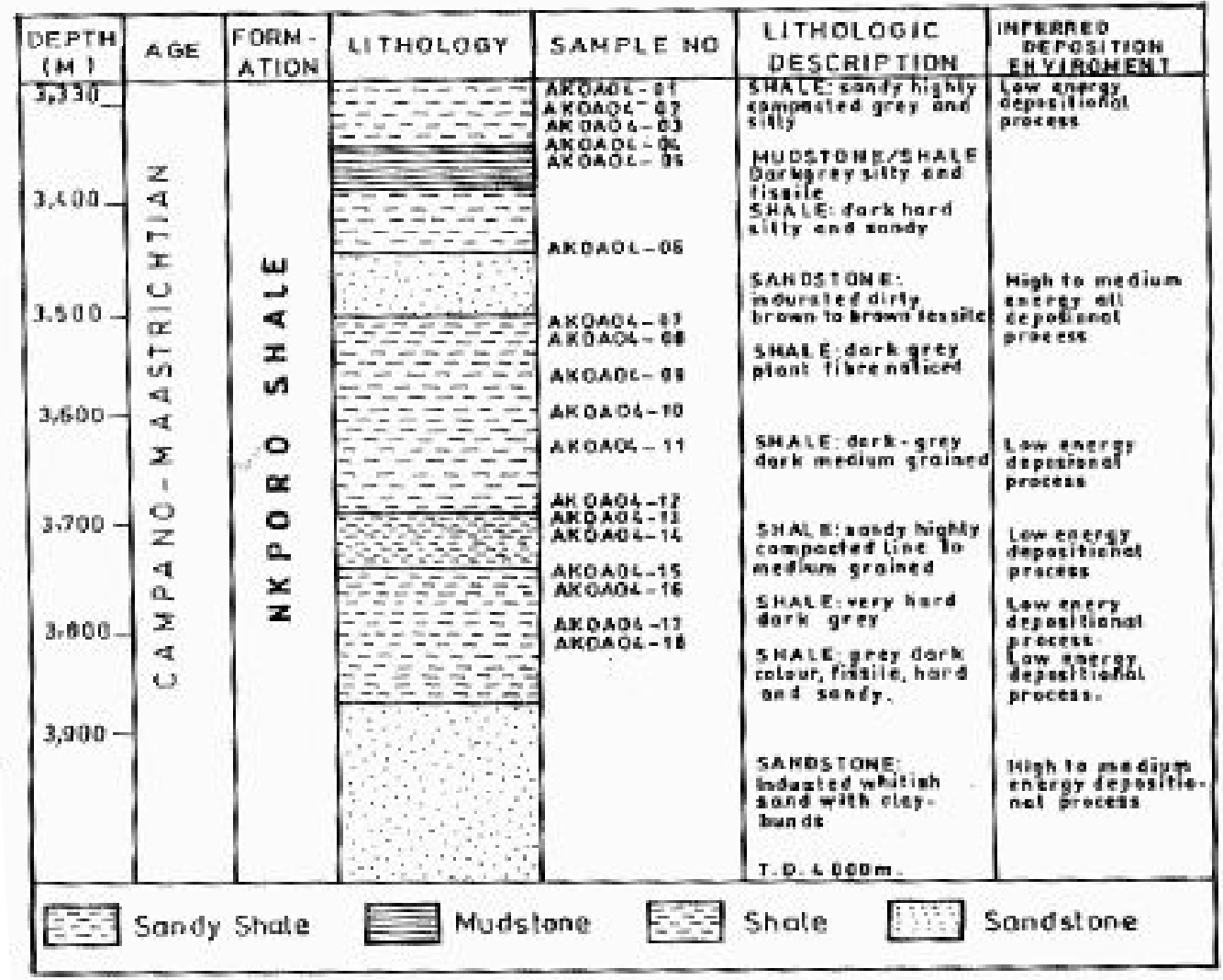

Fig. 4 Lithostratigraphic Log of Akukwa-ll Well. 
well were drilled to evaluate the reservoir qualities of Ajali Sandstone and source rock qualities of Asaka/Nkporo shale.

\section{ANALYTICAL METHODS}

Evaluation of the source rock basically requires the measurement of three parameters which are,

The quality, quantity and maturity of organic matter. In other to characterize organic matter disseminated in the sediments, the following organic geochemical methods were applied.

- Determination of total organic carbon (TOC) using Walkey Black oxidation method. (20)

- Rock - Eval pyrolysis, used to determine hydrocarbon potential as well as evaluating the kerogen type. (20) Espitalie et al (1977).

- Extraction of soluble organic matter using Soxhlet Extraction method.

- $\quad$ Maceral Analysis, was done using reflected light microscope quipped with white incident light and blue light irradiation.

\section{RESULTS AND INTERPRETATION}

- $\quad$ Source rock characterization:-This involve determination of the quantity, quality and
Thermal maturity (Temp) of the organic matter in the sediment.

- DETERMINATION OF THE QUANTITY OF ORGANIC MATTER. Using Black Oxidation method.

- $\quad$ TOC in a sediment is a function of fiz:-presence of Biogenic material, rapid sedimentation/burial and Redox reaction during deposition and diagenesis.

- $\quad$ The minimum TOC concentration necessary for petroleum generation according to Welte (1965) is $0.5 \%$. good peteroleum source rocks usually have higher concentration of organic matter Hunt (1975).

- $\quad$ Table 1 ( $a$ and b) Bitumen ratio Analysis. Ama1 and Aku -11 wells.

- Interpretation: Ama-1 TOC range $0.81-1.42$ Ave $1.3 \%$

Aku-11. TOC range $0.81-1.4 \%$ Ac1.0\%

- $\quad$ TOC decreases with increasing depth.

\section{DETERMINATION OF THE MATURITY OF THE ORGANIC MATTER.}

- Maceral Analysis:- These were done to arrived at the maturity of the organic matter.

Table 1a: Bitumen Ratio Analysis, Amasiodo-1 well

\begin{tabular}{|c|c|c|c|c|c|}
\hline Sample no & $\begin{array}{c}\text { Depth } \\
\text { (meters) }\end{array}$ & Lithology & TOC\% & SOM (ppm) & BR MgExt/gTOC \\
\hline AMOA-0404 & 1522 & SHALE & 0.90 & 32.2 & 3.58 \\
\hline AMOA-0406 & 1575 & SHALE & 0.82 & 30.0 & 3.66 \\
\hline AMOA-0408 & 1640 & SHALE & 1.81 & 128.0 & 7.07 \\
\hline AMOA-0409 & 1673 & SHALE & 1.18 & 44.8 & 3.79 \\
\hline AMOA-0410 & 1680 & SHALE & 1.70 & 47.2 & 2.78 \\
\hline AMOA-0413 & 1703 & SHALE & 1.08 & 60.0 & 5.56 \\
\hline AMOA-0415 & 1765 & SHALE & 1.07 & 68.0 & 6.36 \\
\hline AMOA-0417 & 1800 & SHALE & 1.81 & 30.0 & 3.31 \\
\hline AMOA-0420 & 1900 & SHALE & 1.34 & 80.0 & 5.97 \\
\hline
\end{tabular}

Table 1b: Bitumen Ratio Analysis, Akukwa-II Well

\begin{tabular}{|c|c|c|c|c|c|}
\hline Sample no & $\begin{array}{c}\text { Depth } \\
\text { (meters) }\end{array}$ & Lithology & TOC\% & SOM (ppm) & BR MgExt/gTOC \\
\hline AkOA-0404 & 3300 & SHALE & 1.02 & 96.4 & 9.45 \\
\hline AkOA-0406 & 3474 & SHALE & 1.02 & 80.2 & 7.86 \\
\hline AkOA-0408 & 3514 & SHALE & 1.81 & 180.5 & 22.28 \\
\hline AkOA-0409 & 3543 & SHALE & 1.12 & 75.2 & 6.71 \\
\hline AkOA-0411 & 3575 & SHALE & 0.81 & 55.4 & 6.84 \\
\hline AkOA-0413 & 3619 & SHALE & 0.94 & 30.0 & 3.19 \\
\hline AkOA-0414 & 3647 & SHALE & 1.18 & 47.5 & 4.03 \\
\hline AkOA-0415 & 3680 & SHALE & 1.40 & 3.00 & 2.14 \\
\hline AkOA-0416 & 3700 & SHALE & 0.86 & 47.2 & 5.49 \\
\hline
\end{tabular}




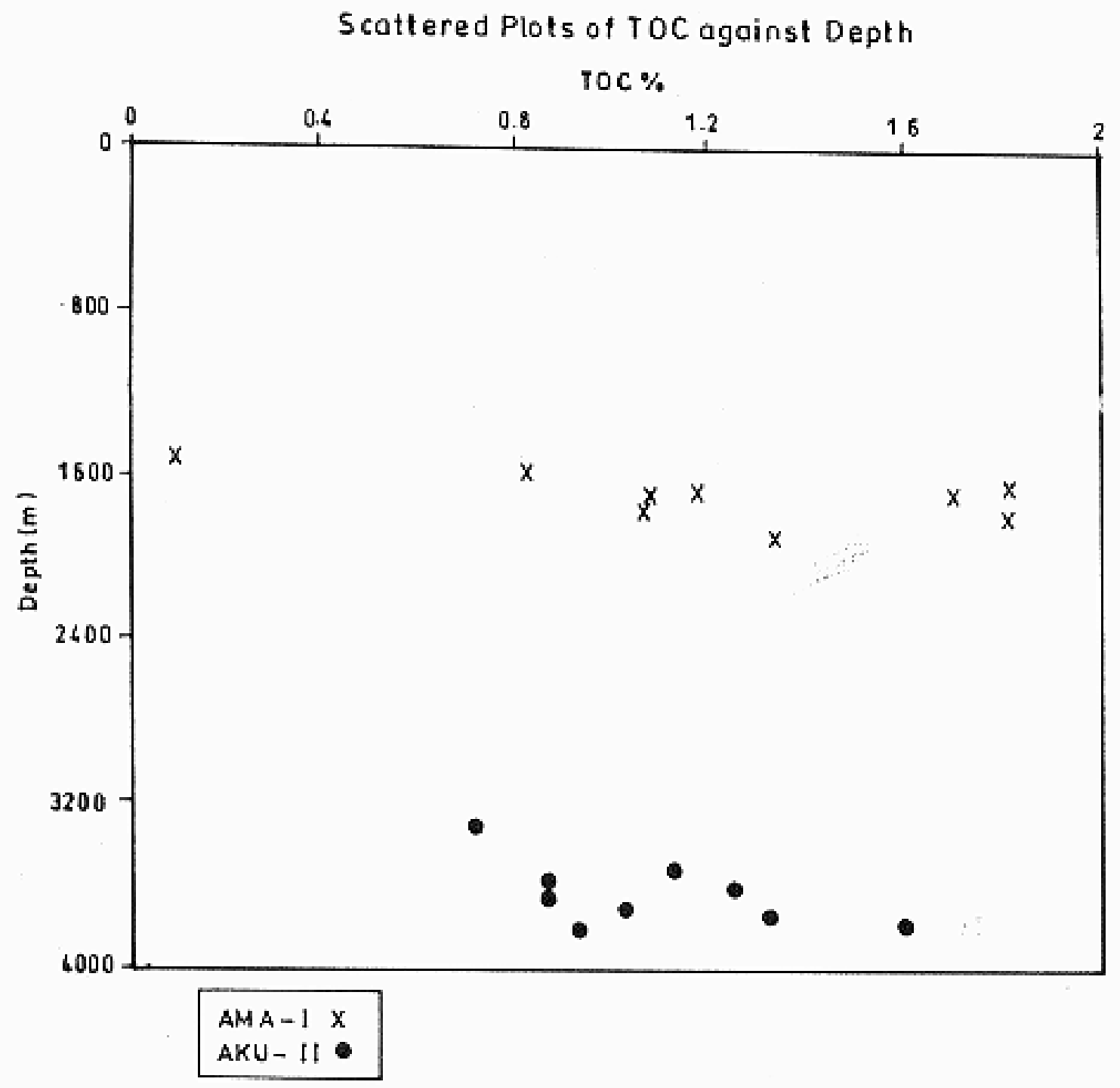

Fig. 5: Plots of TOC against depth Amansiodo-I and Akukwa II wells

- $\quad$ Three groups were classified: vitrinite, (collinite and tellinite mainly woody tissue such as stems, back, root and twigs.

- $\quad$ Liptinite group (Alginite, sporinite, resinite and cuticle) consist of material from algae and resins.

- $\quad$ Intertinite group (macrinite, micrinite etc.). Similar to vitrinite but altered under oxidizing condition.

- Interpretation
- $\quad$ Liptinite-oil prone

- $\quad$ Inertinite - has negligible HC but could generate gas.

Table 2a and b Maceral Analysis Ama -1 and Aku -11 wells. Fig.6. piechart of meceral Analysis.

The chart shows that vitrinite and inertinite percentage are higher than Liptinite percentage. This indicated mainly terrigeneous plants and woody source which is prone to the generation of gas. 
Table 2a: Maceral Analysis, Amasiodo- I well

\begin{tabular}{|c|c|c|c|c|c|c|c|c|c|}
\hline \begin{tabular}{|l|} 
Sample \\
No \\
\end{tabular} & $\begin{array}{l}\text { Depth in } \\
\text { meters }\end{array}$ & Formation & Lithology & Vitrinite & Liptinite & Inertinite & $\begin{array}{l}\text { Mineral } \\
\text { compound }\end{array}$ & Pyrite & Others \\
\hline AMOA-0404 & 1,522 & MAMU & SHALE & 57 & 15 & 9 & 11 & 8 & 19 \\
\hline AMOA- 0406 & 1,575 & MAMU & SHALE & 34 & 28 & 10 & 23 & 5 & 28 \\
\hline AMOA- 0408 & 1,640 & NKPORO & SHALE & 48 & 15 & 12 & 18 & 7 & 25 \\
\hline AMOA-0409 & 1,673 & NKPORO & SHALE & 42 & 25 & 15 & 12 & 6 & 18 \\
\hline AMOA-0410 & 1,680 & NKPORO & SHALE & 40 & 32 & 10 & 12 & 6 & 18 \\
\hline AMOA-0413 & 1,703 & NKPORO & SHALE & 45 & 25 & 8 & 16 & 6 & 22 \\
\hline AMOA-0415 & 1,765 & NKPORO & SHALE & 50 & 20 & 9 & 12 & 9 & 21 \\
\hline AMOA-0417 & 1,800 & NKPORO & SHALE & 48 & 15 & 12 & 18 & 7 & 25 \\
\hline AMOA-0420 & 1,900 & NKPORO & SHALE & 53 & 18 & 9 & 12 & 8 & 20 \\
\hline
\end{tabular}

Table 2b: Maceral Analysis. Akukwa II well

\begin{tabular}{|l|l|l|l|l|l|l|l|l|l|}
\hline $\begin{array}{l}\text { Sample } \\
\text { No }\end{array}$ & $\begin{array}{l}\text { Depth } \\
\text { in meters }\end{array}$ & Formation & Lithology & Vitrinite & Liptinite & Inertinite & $\begin{array}{l}\text { Mineral } \\
\text { compound }\end{array}$ & Pyrite & \begin{tabular}{l} 
Others \\
\hline AKOA-0405
\end{tabular} \\
3,360 & NKPORO & SHALE & 43 & 18 & 7 & 22 & 10 & 32 \\
\hline AKOA-0406 & 3,474 & NKPORO & SHALE & 50 & 20 & 10 & 14 & 7 & 21 \\
\hline AKOA-0408 & 3,514 & NKPORO & SHALE & 55 & 10 & 5 & 21 & 9 & 30 \\
\hline AKOA-0409 & 3,543 & NKPORO & SHALE & 40 & 32 & 10 & 12 & 6 & 18 \\
\hline AKOA-0411 & 3,576 & NKPORO & SHALE & 35 & 22 & 12 & 26 & 5 & 31 \\
\hline AKOA-0413 & 3,619 & NKPORO & SHALE & 38 & 29 & 5 & 19 & 9 & 28 \\
\hline AKOA-0414 & 3,647 & NKPORO & SHALE & 65 & 18 & 4 & 8 & 5 & 13 \\
\hline AKOA-0415 & 3,680 & NKPORO & SHALE & 30 & 25 & 15 & 25 & 12 & 37 \\
\hline AKOA-0416 & 3.700 & NKPORO & SHALE & 22 & 31 & 8 & 27 & 12 & 39 \\
\hline
\end{tabular}


IG. 6 - PIE CHART OF MACERAL ANALYSIS FOR AMANSIODO-1 WELL
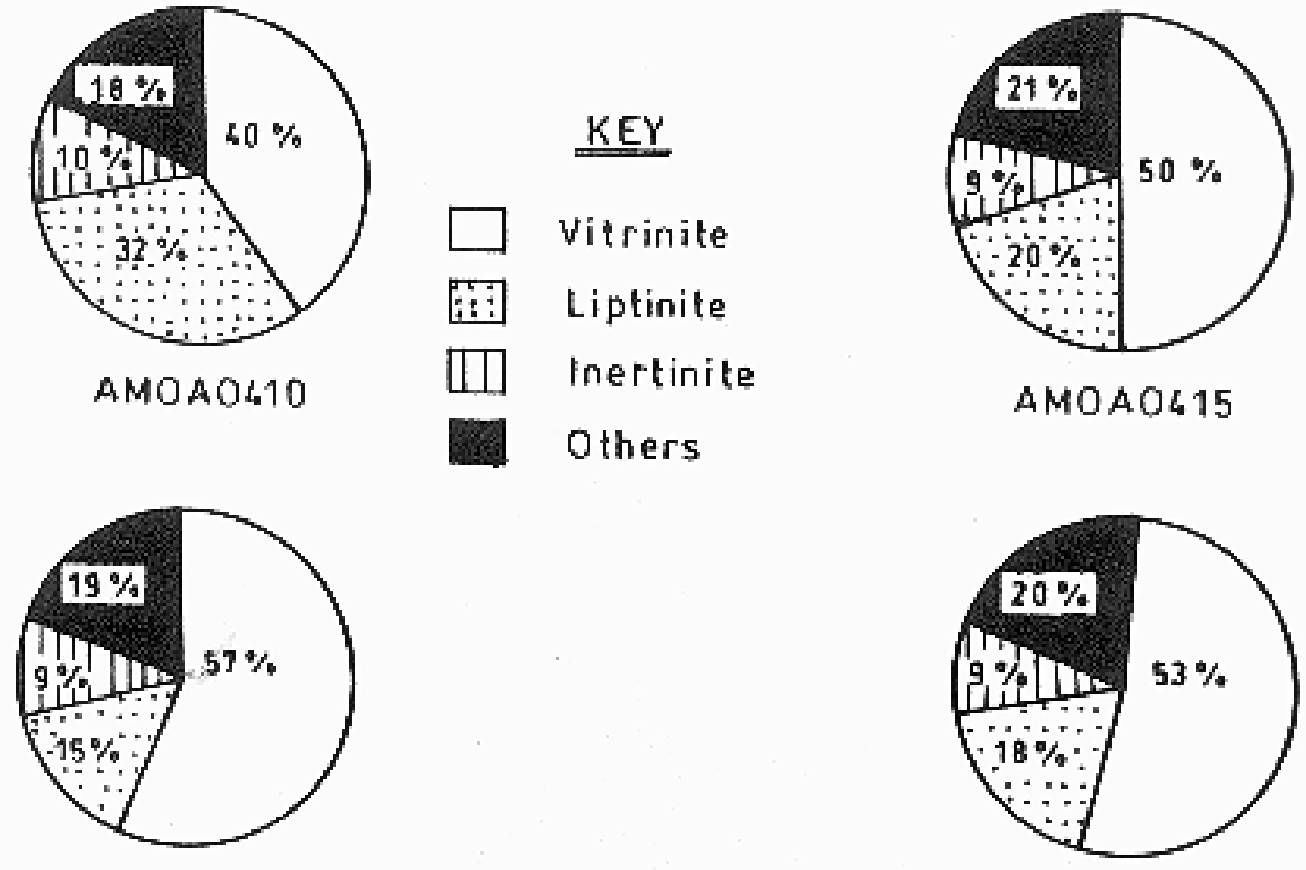

AMOAO41L

AMOAO 420
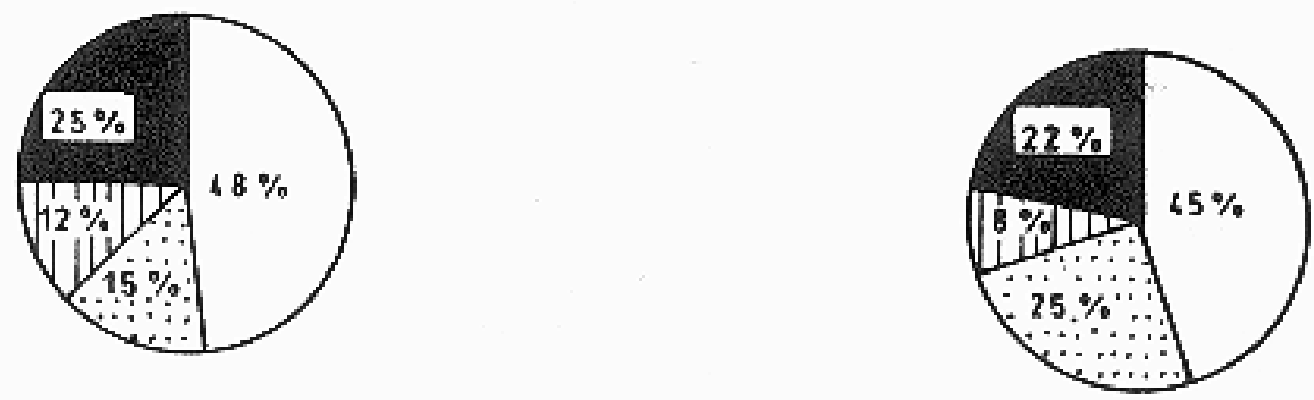

AMOAO 617

AMOAO413 
FIG. 6D: PIE CHARTS OF MACERAL ANALYSIS FOR AKUKWA-IIWELLS

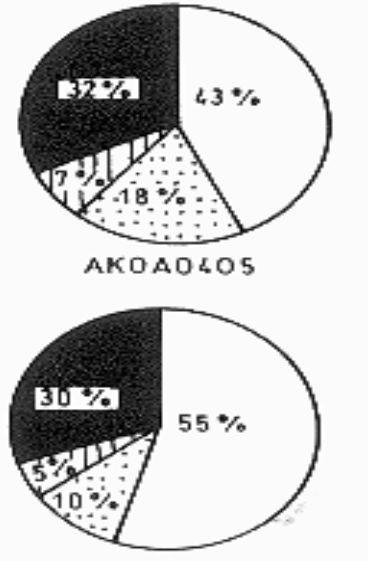

AKOAO $4 O B$
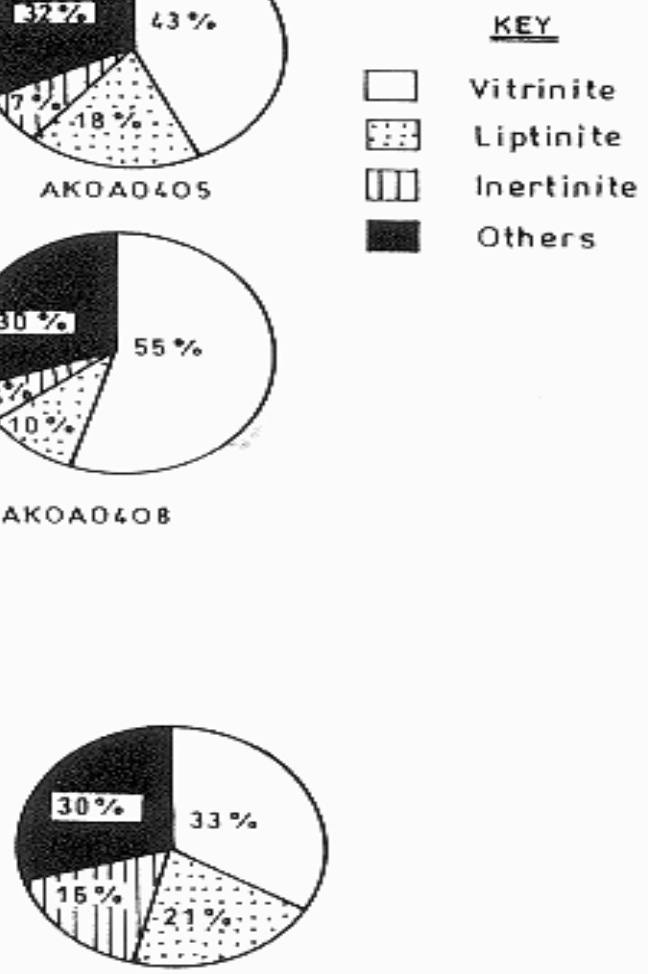

АКОАО 411

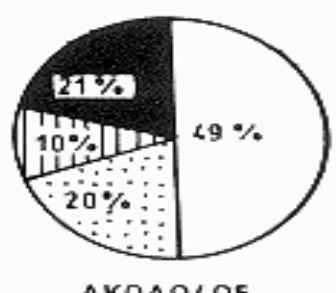

AKOAOLOE

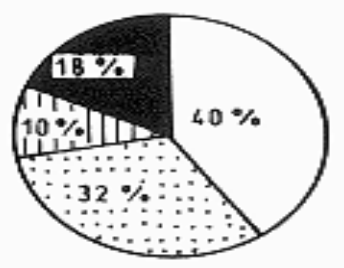

AKOAOLO9

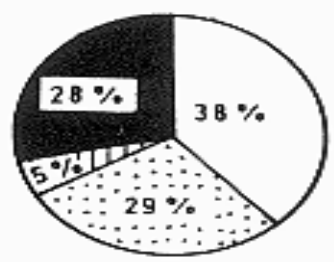

$\triangle K O A O \angle 13$

\section{DETERMINATION OF THE KEROGEN TYPE}

\section{EVAL PYROLYSIS METHOD}

\section{ROCK-Eval Pyrolysis (Analysis)}

Table; 3a and b Rock Eval Analysis. Ama -1 and Aku 11 wells

- $\quad$ This involves heating small amount of sample between $250^{\circ} \mathrm{C}$ and $550^{\circ} \mathrm{C}$ in the absence of oxygen (Thermal decomposition reaction).

- $\quad$ S1 - Peak: quantity of free hydrocarbon (HC) Librated by volatilization at $250^{\circ} \mathrm{C}$. $(\mathrm{mgHc} / \mathrm{g}$ rock).

- $\quad$ S2 - peak: quantity of HC produced by further hearting of kerogen. (mgHc/g rock). Present day ability of the kerogen to generate $\mathrm{HC}$.
- $\quad \mathrm{S} 3$ - peak - C02 released from the kerogen at the end.

- Dymann et al (1996) gave the following classification

- $\quad$ Lower than $2 \mathrm{mgHc} / \mathrm{grock}$ (2000ppm) - Little or no source potential but some potential for gas.

- 2 to $6 \mathrm{mgHC} /$ grock $(2,000-6,000 \mathrm{ppm})=$ moderate or fair source rock potential.

\section{Interpretation}

- The Rock-Eval Analysis of both wells (Ama-1 and Aku-11) revealed the following values of $S 1$ peak; Ama-1 (0.03 to 0.28) 
Table .3 a: Roc k-Eval Analysis, Ama-I Well

\begin{tabular}{|l|l|l|l|l|l|l|l|l|l|l|}
\hline Sample no & $\begin{array}{l}\text { Depth } \\
\text { meters }\end{array}$ & Formation & $\begin{array}{l}\text { TOC } \\
(\%)\end{array}$ & $T^{\circ} \mathrm{C}$ & $\mathrm{S} 1$ & $\mathrm{~S} 2$ & $\mathrm{~S} 3$ & $\mathrm{PI}$ & $\mathrm{HI}$ & 01 \\
\hline AMOA-04-04 & 1522 & MAMU & 0.09 & 426 & 0.04 & 0.053 & 1.62 & 0.07 & 59 & 180 \\
\hline $\begin{array}{l}\text { AMOA- } \\
04-06\end{array}$ & 1575 & MAMU & 0.82 & 443 & 0.03 & 1.12 & 7.28 & 0.03 & 137 & 888 \\
\hline $\begin{array}{l}\text { AMOA- } \\
\text { 0408 }\end{array}$ & 1640 & NKPORO & 1.81 & 440 & 0.17 & 4.14 & 2.24 & 0.04 & 229 & 124 \\
\hline $\begin{array}{l}\text { AMOA- } \\
0409\end{array}$ & 1673 & NKPORO & 1.18 & 437 & 0.28 & 5.39 & 2.29 & 0.05 & 451 & 228 \\
\hline $\begin{array}{l}\text { AMOA- } \\
0410\end{array}$ & 1680 & NKPORO & 1.70 & 438 & 0.15 & 3.34 & 2.45 & 0.04 & 196 & 144 \\
\hline $\begin{array}{l}\text { AMOA-0413 } \\
1703\end{array}$ & NKPORO & 1.08 & 450 & 0.10 & 1.23 & 1.48 & 0.08 & 114 & 137 \\
\hline AMOA-0415 & 1765 & NKPORO & 1.07 & 471 & 0.12 & 0.32 & 1.42 & 0.27 & 30 & 133 \\
\hline AMOA-0417 & 1800 & NKPORO & 1.81 & 442 & 0.04 & 1.25 & 1.24 & 0.03 & 69 & 105 \\
\hline AMOA-0420 & 1900 & NKPORO & 1.34 & 428 & 0.13 & 0.45 & 1.36 & 0.22 & 34 & 102 \\
\hline
\end{tabular}

Table 3b: Rock-Eva Analysis, Aku-II Well

\begin{tabular}{|l|l|l|l|l|l|l|l|l|l|l|}
\hline Sample no & $\begin{array}{l}\text { Depth } \\
\text { meters }\end{array}$ & Formation & $\begin{array}{l}\text { TOC } \\
(\%)\end{array}$ & $T^{\circ} \mathrm{C}$ & S1 & S2 & S3 & PI & HI & 01 \\
\hline AMOA-04-05 & 3300 & NKPORO & 0.69 & 467 & 0.04 & 2.55 & 1.80 & 0.02 & 370 & 261 \\
\hline $\begin{array}{l}\text { AMOA- } \\
\text { 44-06 }\end{array}$ & 3474 & NKPORO & 1.02 & 487 & 0.10 & 4.01 & 2.45 & 0.02 & 393 & 240 \\
\hline $\begin{array}{l}\text { AMOA- } \\
\text { 0408 }\end{array}$ & 3514 & NKPORO & 0.81 & 478 & 0.10 & 2.37 & 2.40 & 0.06 & 293 & 296 \\
\hline $\begin{array}{l}\text { AMOA- } \\
\text { 0409 }\end{array}$ & 3543 & NKPORO & 1.12 & 480 & 0.20 & 3.30 & 2.30 & 0.07 & 395 & 205 \\
\hline $\begin{array}{l}\text { AMOA- } \\
0411\end{array}$ & 3572 & NKPORO & 0.81 & 493 & 0.26 & 3.41 & 2.74 & 0.07 & 421 & 338 \\
\hline $\begin{array}{l}\text { AMOA- } \\
0413\end{array}$ & 3619 & NKPORO & 1.94 & 496 & 0.10 & 3.77 & 3.08 & 0.04 & 401 & 328 \\
\hline $\begin{array}{l}\text { AMOA- } \\
0414\end{array}$ & 3647 & NKPORO & 1.18 & 434 & 0.20 & 4.01 & 3.22 & 0.05 & 340 & 273 \\
\hline AMOA-0415 & 3680 & NKPORO & 1.40 & 415 & 0.15 & 1.03 & 2.99 & 0.12 & 114 & 207 \\
\hline $\begin{array}{l}\text { AMOA- } \\
\text { 0416 }\end{array}$ & 3700 & NKPORO & 0.86 & 484 & 0.21 & 3.15 & 2.95 & 0.06 & 366 & 343 \\
\hline
\end{tabular}

$\mathrm{mgHc} / \mathrm{g}$ rock) Ave $0.12 \mathrm{mgHc} / \mathrm{grock}$. Aku -11 (0.04-0.26mgHc/g rock) Ave $0.15 \mathrm{mgHc} / \mathrm{g}$ rock.

- $\quad$ Since the values of $\mathrm{S} 1$ peak for both wells is less than $2 \mathrm{mgHC} / \mathrm{g}$ rock. This revealed little or no source potential for oil but some potential for gas.

- Values of $\mathrm{S} 2$ peak - revealed high amount of $\mathrm{CO}_{2}$ released after the whole reaction, this is equivalent to the amount of oxygen in the sample.

Fig. 7; plots of $\mathrm{HI}$ vs T max. Ama-1 and Aku -11 wells. 


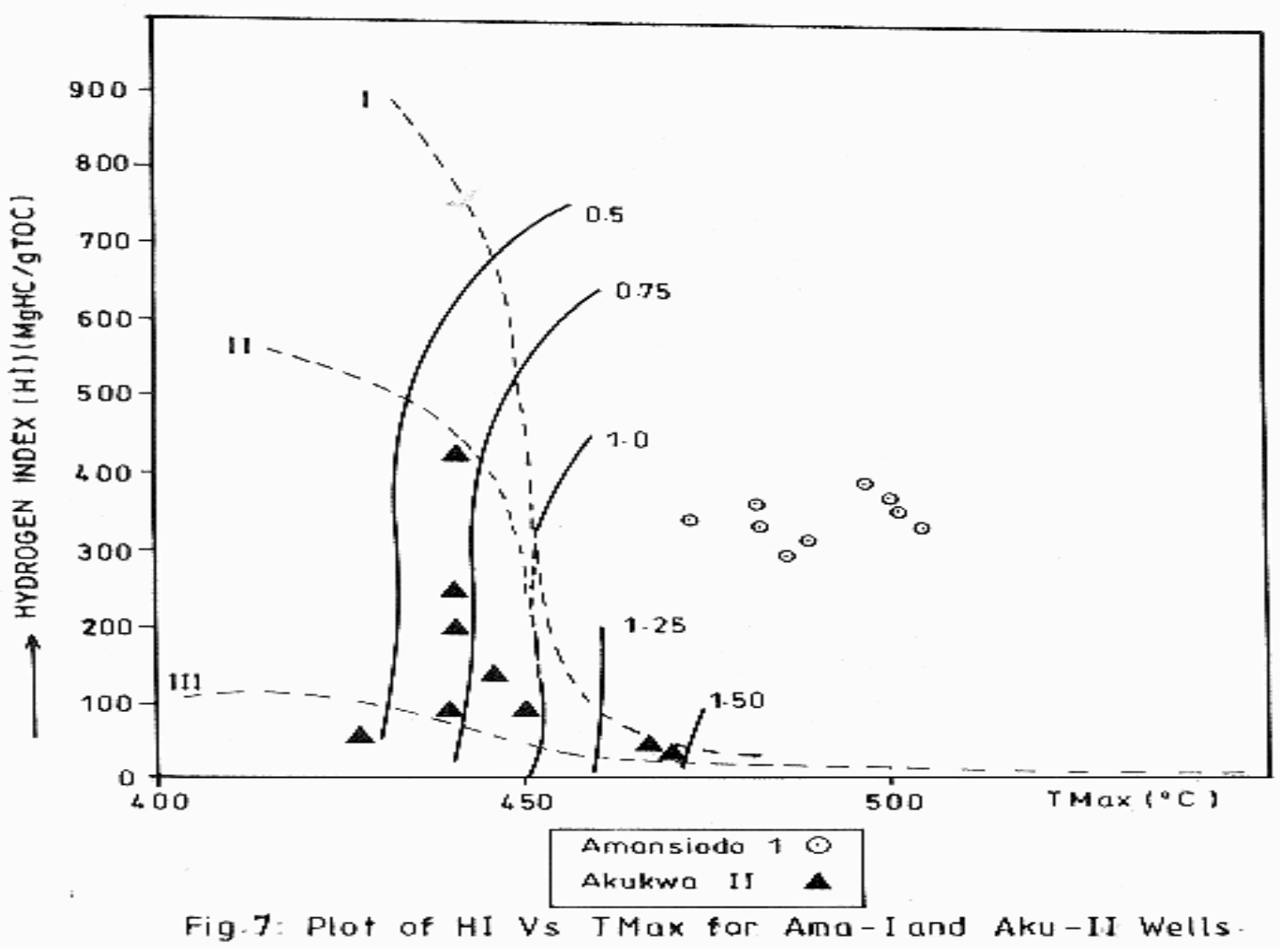

Ama-1 well plots within Type II and III kerogene.

That of Aku - II well is outside the field, this may be due to the contamination of the samples.

Fig. 8; plots of HI vs 0l for Ama-1 well and Aku-II wells. Ama-1 plots within Type II and III. That of Aku - II well is outside the field.

Fig. 9; plot of HI vs TOC, Ama-1 and Aku-11 wells.

The plots revealed increase TOC with increasing $\mathrm{HI}$ for both wells.

Fig. 10; plot of Bitumen ratio (mgExt/gTOC) vs depth for Ama-1 and Aku-ll wells.

The plots show. a decrease in $\mathrm{BR}$ (Bitumen ratio) with increasing depth for both wells.

Fig 7. is an evolution diagram drawn to assess the extent of thermal effect on the organic matter and to cross check the validity of the hydrogen index (HI) of the kerogens as a function of T-max. Most of the samples from Amansiodo-1 well plot along the type II kerogen evolution pathway except one which follow the type III kerogen pathway.

The Aku - II well samples plotted outside the field this may be due to sample contamination. Most of the samples of Ama-1 well are relatively immature plotting below and around $0.5 \% \mathrm{Rm}$ boundary line and majority having T-max value quite below $450^{\circ} \mathrm{C}$.

Fig 8:- The samples from Ama -1 well have very low values of $\mathrm{HI}$ and high values of 01 and plot mainly along the type III and II kerogen evolutionary pathway. The low hydrogen index $\mathrm{HI}$ values point to type II and III organic matter deposited perhaps in an oxidizing environment. The high values of Ol may equally be due to relatively high content of carbonate minerals with lower TOC values $(<2 \%)$. It must be noted that all the samples are relatively immature and are no source rocks. The plots of Akukwa - II are generally outside the field, this may be due to sample contamination.

Fig 9:. A plot of $\mathrm{HI}$ against TOC for both Ama -1 and Aku -ll wells. The values for Ama-I is (0.09\%-1.8\%) with only a sample having value less than $0.5 \%$. Aku - II values range from $(0.69 \%$ to $9.94 \%)$. The $\mathrm{HI}$ of Ama-I well were found to be lower than that of Aku-Il well this is due to the depth of burial.

Fig 10:. The plot of Bitumen ratio against depth Show no variation in the extractable organic matter (EOM) or bitumen from the samples. The bitumen ratio in Ama-I well vary from 2.78 to 7.07 and Aku-II from 2.14 to 9.45 with a point having a value of 22.28 . There is no clear or definite trend of the extractable yield with depth which is of course a function of geothermal gradient and temperature. However there is a slight increase of the value at depth 3,514 meters in Aku-Il well. 


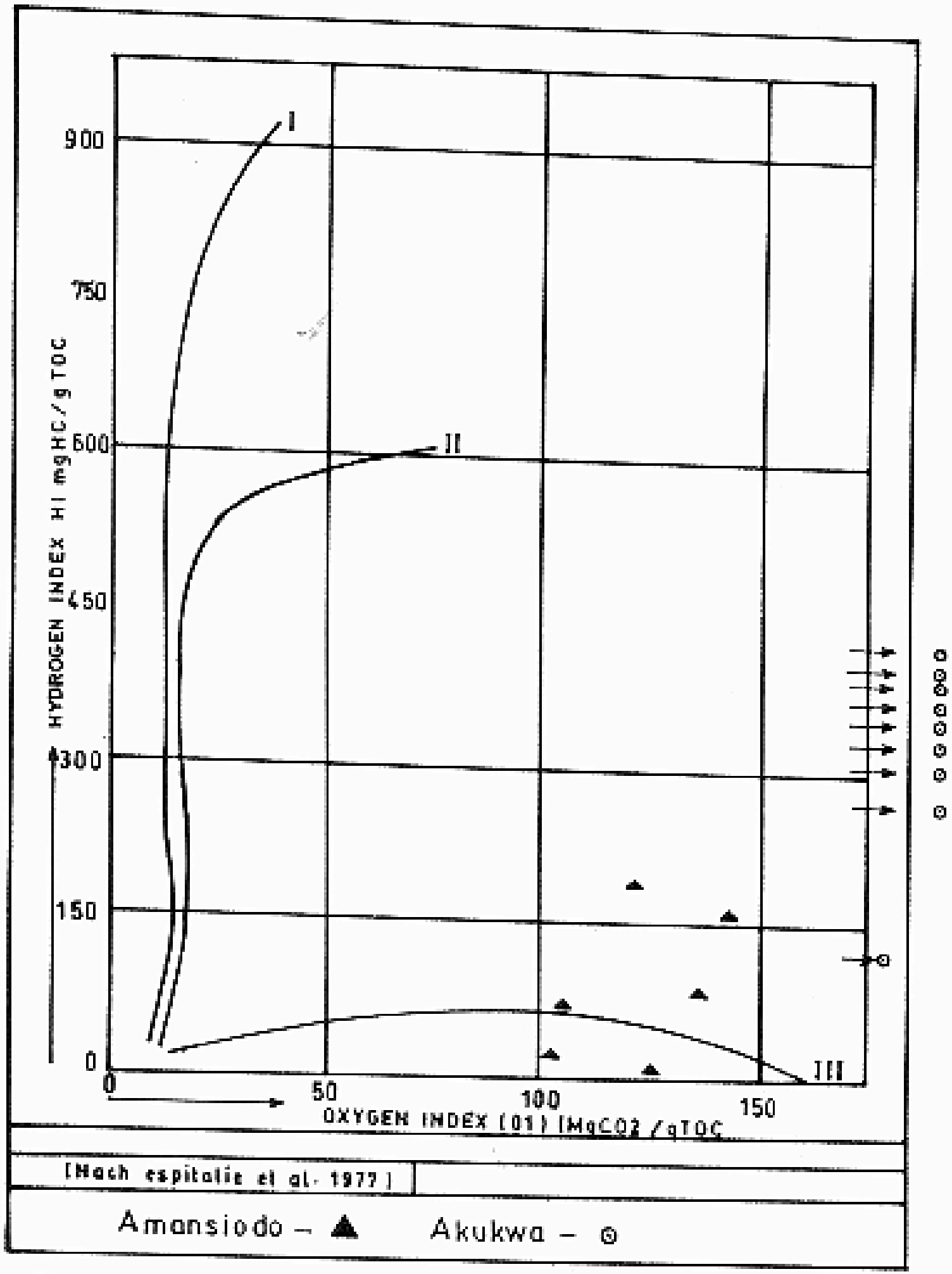

Fig. B: Plots of HI Vs OI for Ama-I and Aku-II Wells 


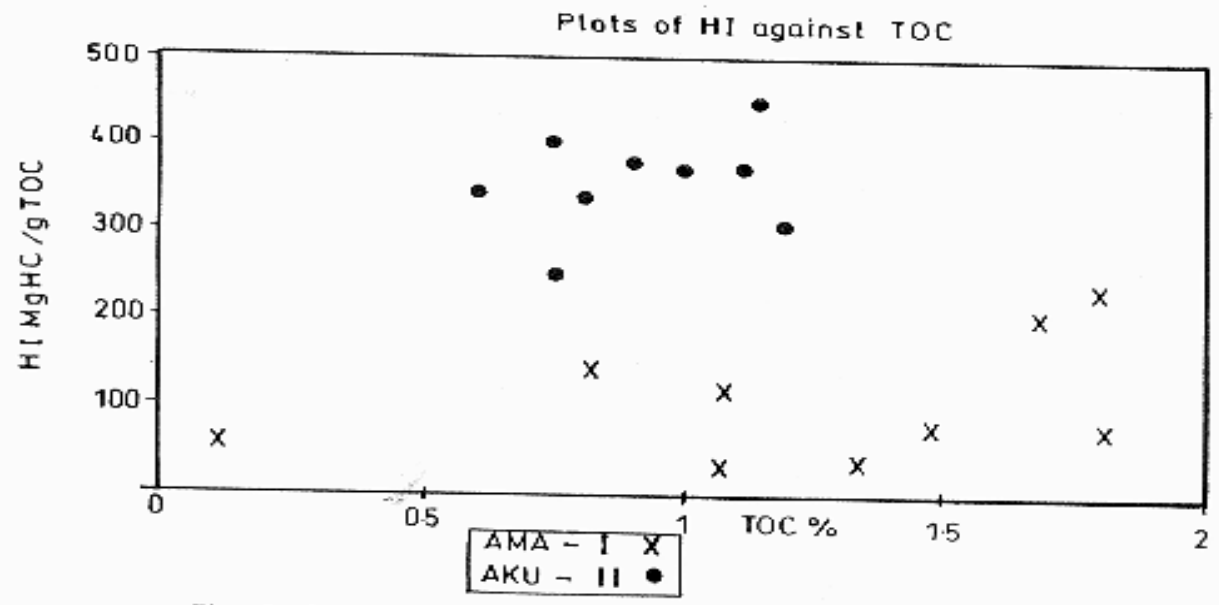

Fig. 9: Plots of HI against TOC, Ama-I and Aku-II Wells

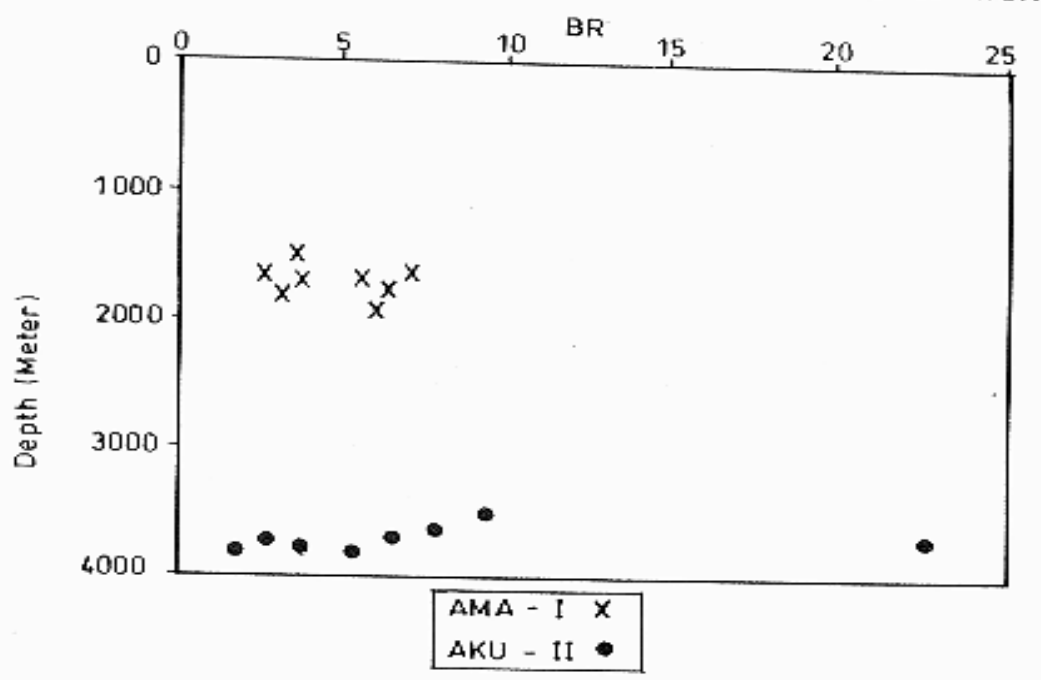

Fig. 10: Plots of Bitumen ratio against depth Amansiodo - I and Akukwa-II Wells.

Fig 11:. The plot of SOM against depth. In Ama $-I$ well, the values of SOM range from (30.0 to $80.0 \mathrm{ppm})$ with a high value of $128 \mathrm{ppm}$ at a depth of 1,640 meters. The same variation was in Aku-ll well with values ranging from $30.0 \mathrm{ppm}$ to $96.4 \mathrm{ppm}$ with a high value of $180.5 \mathrm{ppm}$ at a depth of 3,514 meters. The plots of Ama -I well show a slight increase with increasing depth which shows that it is a function of geothermal gradient and temperature, on the contrary the plot of Aku-II show also a slight decrease in SOM values with increasing depth this is also a function of geothermal gradient and temperature.

Fig 12:- The T-max $\left({ }^{0} \mathrm{C}\right)$ is a pyrolysis parameter that respond to the thermal maturity of kerogen, it is the temperature corresponding to the maximum hydrocarbon pyrolytic yield i.e maximum of $S_{2}$ peak in the Rock-Eval Pyrogram. The T-max varies as a function of the thermal maturity of organic matter (TISSOT and ESPITALIE 1974). T max is also linked to the kinetics of the cracking of the organic mater contained in the kerogen (AKAEGBOB 1995).
For Ama-I well the T-max values range is from $426^{\circ} \mathrm{C}-471^{\circ} \mathrm{C}$, for Aku-II well T-max values range is from $415^{\circ} \mathrm{C}-496^{\circ} \mathrm{C}$. In both well the T-max was found to vary slightly with depth; it increases with increasing depth, this show that the T-max is a function of the geothermal gradient and the temperature. From the diagram of the relationship between T-max, kerogen types and oil and gas windows (after BORDENAVE et al 1993), the oil generating window for a type III kerogen is from $430^{\circ} \mathrm{C}$ to $470^{\circ} \mathrm{C}$ and for a type II kerogen is from $430^{\circ} \mathrm{C}$ to $455^{\circ} \mathrm{C}$.

The T-max results of the two wells vary from one sample to the other. The T-max values of up to $471^{\circ} \mathrm{C}$ were observed for the Ama-I well and up to $496^{\circ} \mathrm{C}$ for Aku-II well. Since the threshold of hydrocarbon generation (THG) for kerogen II and III is $430^{\circ} \mathrm{C} \mathrm{T-max}$ the samples from both well are thermally

matured to generate oil and gas. 


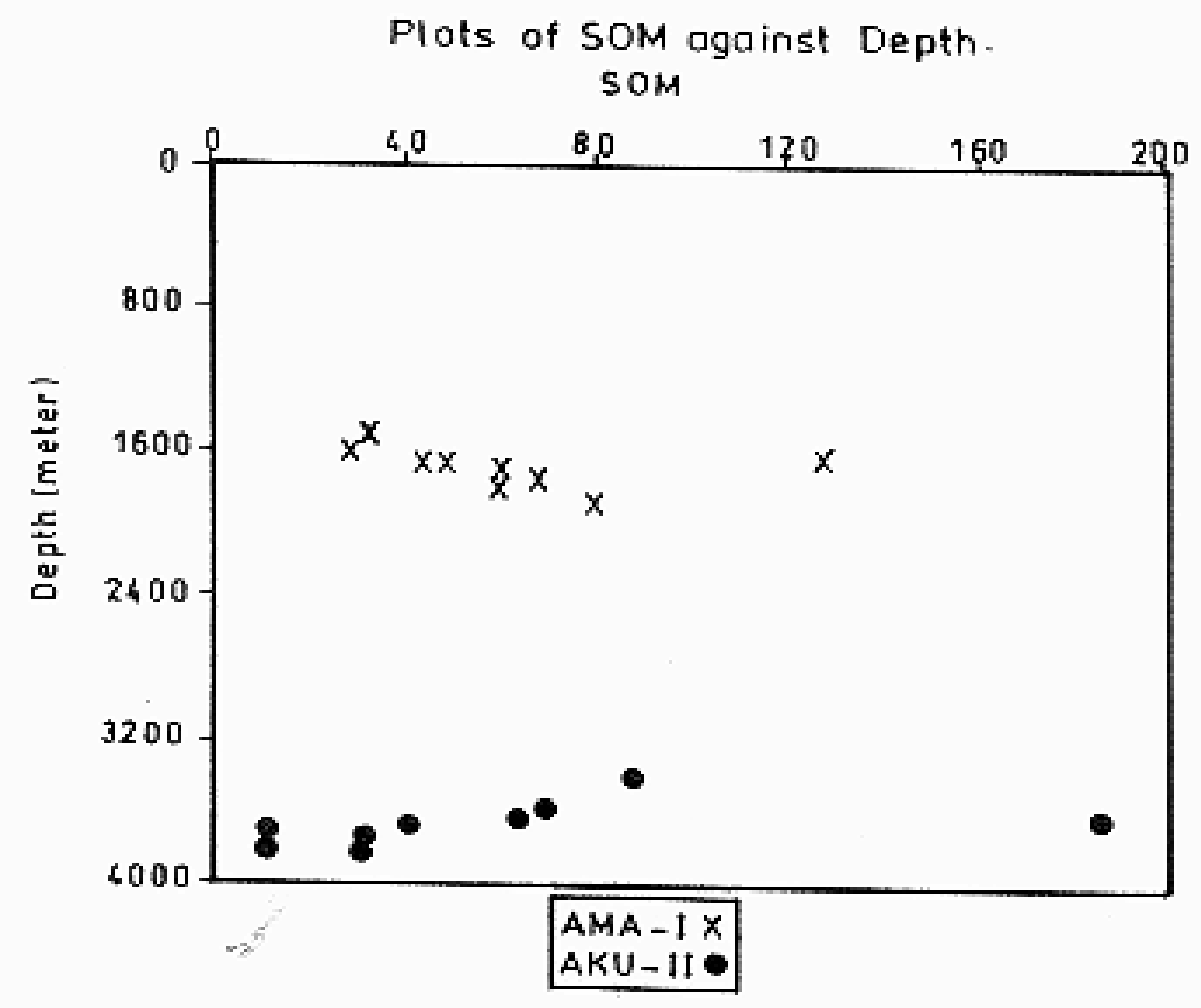

Fig.11: Plots of SOM against depth Amansiodo-1 and Akukwa-11 wells.

Plats of $T$ - max against Depth.

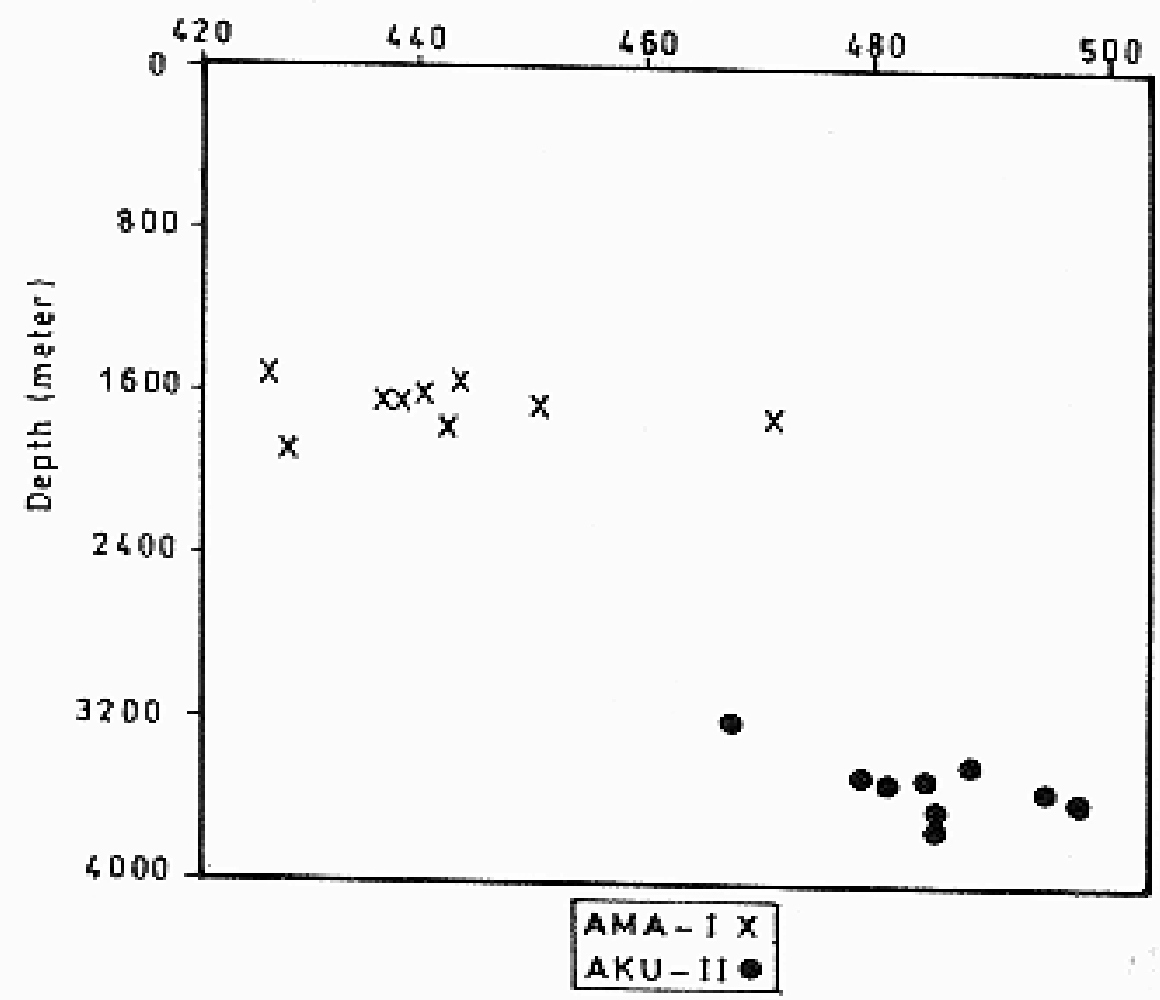

Fig-12:Plots of T-Max against Depth Amansiodo-1 and Akukwa - 11 wells. 


\section{CONCLUSION}

The Shales were found to contain enough total organic carbon (TOC) and enough extractable organic matter to generate enough hydrocarbon $(\mathrm{HC})$

The result of Maceral analysis as indicated by the pie-chart revealed high vitrinite and inertinite values to Liptinite in both wells; since the percentage of vitrinite is high there is tendency for the shale to generate gas. The plot of Hydrogen index against temperature maximum (T-max), which gives the vitrinite reflectance measure indicate that the shale samples could only generate dry-gas.

Rock-Eval pyrolysis results revealed that shales of Nkporo has Hydrogen index of more than 200 which implies that significant oil can be generated from the shale. The cross plot of Hydrogen index and oxygen index revealed that the shale can only generate Type II and Type III kerogens. The T max value of $430^{\circ} \mathrm{C}$ to $490^{\circ} \mathrm{C}$ also revealed that the source rocks are matured enough to generate oil and gas since the threshold of hydrocarbon generation (THG) for kerogen II and III is $430 \mathrm{~T}$-max

The Rock-Eval and T-max values give relatively good results especially for TOC-rich samples which is the case of the basins of sedimentary rocks with predominantly terrestrial organic matter, this is also revealed by the organic matter to be mainly type II and III kerogen which also suggest derivation mainly from terrestrial higher plants, these results reflects immature to early mature stages of organic matter (OM).

\section{REFERENCES}

Agagu, O. K., 1978. Geology and petroleum potential of santonian to Maastrichtian sediments in the Anambra basin, Eastern Nigeria (Ph.D Thesis)

Agagu, O.K. and Ekweozor, C.M., 1980. Petroleum geology of senonian sediments in Anambra syncline, southeastern Nigeria (abs.) -Bull. Assoc. petrol. Geol. 64 pp Tulsa.

Agagu, O.K., Fayose, E.A and Petters, S.W., 1986. Sratigraphy and sedimentation in the senonian Anambra basin of Eastern Nigeria- Nig. Journ, $\min$. Geol, 22, 25-36.

Akaegbobi, I.M, J.I. Nwachukwu, and M. Schmitt, 2000. Aromatic hydrocarbon distribution and calculation of oil and gas volumes in postsantonian shale and coal, Anambra basin, Nigeria, in M.R. Mello and B.J. Katz, eds, Petroleum Systems of South Atlantic margins: AAPG memoir 73, 233-245.

Akaegbobi, M., 1995. The Petroleum province of Southern Nigerian-Niger Delta and Anambra basin: organic Geochemical and organic petrographic approach.
Avbovbo, A. A., 1978a. Geothermal gradients in the Southern Nigeria Canad petrol. Geo, 26, 268274. Basin: Bul.

Bain, A.D.N., 1924. The Nigeria, Coal field, section 1 Enugu area Bull. Geol. Surv. Nigeria, No 6.

Bain, A.D.N., 1930. The Nigeria coal field: Ann. Rep Geol. Surv Nigeria p 6 -10.

Ekweozor, C.M. and Gormly, J.R., 1983. Petroleum geochemistry of late Cretaceous and early Tertiary shales penetrated by the Akukwa-II well in the Anambra Basin, Southern Nigeria J. Petrol. Geol. 6,207-216 Reading.

Espitalie. J. Madec, M. Tissot, B and Leplat, P., 1977. Source rock characterization method for petroleum exploration offshole Tech no. Confer. OTC 2935, 439-41 Houston.

Hunt, J.M. and Jamieson, G.E., 1965. Oil and organic matter in source rock of petroleum: Amer. Assoc. Petroleum Geologists Bull., 40 P. 477488.

Olade, M.A., 1975. Evolution of the Nigeria Benue Trough - a techonic model Geol.mag. 112, 575583.

Petters, S.W. and Ekweozor, C.M., 1982. Petroleum geology of Benue Trough and southeastern chad basin, Nigeria- Bull. Amer. Assoc. Petrol. Geol, 66,1141-1149, Tulsa.

Reyment, R.A., 1965. Aspects of the Geology of Nigeria: Ibadan, Nigeria, Univ. Ibadan.

Tissot, B, Durand, B., Espitalie, J. and Combaz, A.,

1974. Influence of nature and diagenesis of organic matter information of petroleum-Bull. Amer. Assoc. Petrol. Geol., 58, 499-506, Tulsa.

Welte, D. H., 1965. Relations between petroleum and source rocks Am. Assoc. petroleum geologists Bull. 49. p 2246-2268.

Wilson, R.C and Bain, A.D.N., 1928. The Nigerian coalfield section II, parts of Onitsha and Owerri provinces. Bull Geol. Surv. Nigeria, 2: 
